\title{
KANTIN KEJUJURAN SEBAGAI SARANA PENANAMAN SIFAT JUJUR PADA PESERTA DIDIK DI SEKOLAH TINGKAT DASAR
}

\author{
Tri Ratna Dewi, Miftahur Rohmah, Rely Kurniawan \\ Sekolah Tinggi Keguruan Ilmu dan Pendidikan (STKIP) \\ Nurul Huda, OKU Timur, Sum-Sel
}

\begin{abstract}
Abstrak
Tujuan dari penulisan artikel ini untuk mengetahui bagaimana pengelolaan kantin kejujuran sebagai sarana untuk menanamkan sifat jujur kepada peserta didik. Kantin kejujuran merupakan kantin yang tidak sama seperti kantin biasanya, pada kantin kejujuran tidak ada pelayanan jual beli, peserta didik ketika membeli melayani dirinya sendiri, dengan diterapkannya kantin kejujuran disekolah pastinya memberikan dampak pada sifat jujur peserta didik yakni dampak pada kejujuran ketika berbicara, jujur ketika bermuamalah, jujur ketika berjanji. Pihak sekolah tentu mendukung sepenuhnya dengan pengembangan kantin kejujuran ini. Menanamkan pendidikan akhlak sejak dini, diperlukan sarana dan media yang tepat dalam rangka mentransformasikan pendidikan tersebut kepada anak didik. Salah satu sarana yang dapat digunakan untuk mengajarkan dan membiasakan kejujuran kepada anak didik adalah melalui penerapan kantin kejujuran.
\end{abstract}

\begin{abstract}
The purpose of writing this article is to find out how honest honest canteen management is as a means to instill honesty in students. An honesty canteen is a canteen that is not the same as a normal canteen, in an honesty canteen there is no buying and selling service, students when buying serve themselves, by applying the honesty canteen at school certainly has an impact on the honesty of students namely the impact on honesty when speaking, honestly when bermuamalah, honest when promised. . The school certainly fully supports the development of this honesty canteen. Instilling moral education from an early age, the right means and media are needed in order to transform education to students. One of the tools that can be used to teach and familiarize honesty with students is through the application of the honesty canteen.
\end{abstract}

Kata Kunci: kantin kejujuran, penanaman sifat jujur

\section{PENDAHULUAN}

Dalam sebuah pendidikan terdapat proses pembentukan kesadaran dan kepribadian peserta didik dengan cara pewarisan nilai-nilai keagamaan, kebudayaan, pemikiran, dan keahlian. Melalui proses pendidikan diharapkan akan lahir generasi-generasi penerus yang berkarakter, insan kamil yang bertaqwa, berilmu, dan berakhlak mulia. Akhlak merupakan bentuk jamaee dari khuluq yang berarti perangai atau tabiat. Dijelaskan di dalam kitab Ihya ${ }^{e e}$ Ulumudin, Ibnu Masykawih berpendapat bahwa akhlak adalah suatu sifat yang tertanam di dalam jiwa, darinya timbul perbuatan-perbuatan dengan mudah dan tidak memerlukan 
pertimbangan-pertimbangan pikiran terlebih dahulu (Ammar, 2013:400). Sedangkan menurut Ahmad Amin (dalam Abdud, 2000:9) akhlak adalah kehendak yang dibiasakan. Lebih mendalam lagi akhlak adalah implementasi dari iman dalam segala bentuk perilaku (Darajat, 1993:58).

Beberapa pengertian di atas dapat diambil kesimpulan bahwa akhlak merupakan perbuatan-perbuatan yang telah mempribadi dan membiasa (menjadi sebuah kebiasaan), menjadikan berkarakter pada diri seseorang, dilakukan secara berulang-ulang dengan kesadaran jiwanya. Akhlak ini merupakan perbuatan yang dapat diukur dengan ukuran baik (akhlak mahmudah) dan buruk (akhlak mazmumah). Salah satu akhlak mahmudah adalah shidiq atau yang kita kenal dengan jujur. Perilaku jujur berbicara yang baik dan sopan merupakan sebuah sifat, sikap, atau kebiasaan, sehingga kejujuran tidak bisa dipaksakan secara instan, harus melalui proses pembiasaan sejak lama. Untuk membuat sesuatu pekerjaan menjadi sebuah kebiasaan perlu adanya pengulangan pekerjaan yang terus menerus, seperti itu halnya dalam penanaman sifat jujur pada peserta didik perlu adanya latihan yang diulang-ulang (terus-menurus) biar menjadi sebuah pembiasaan.

Oleh karena itu pendidikan karakter yang mengajarkan nilai-nilai moral menjadi keharusan bagi sekolah untuk mulai diterapkan di sekolah maupun di madrasah. Pendidikan nilai (kejujuran, disiplin, saling menghargai, cinta lingkungan daya juang, bersyukur, dan lain-lain) bukan menjadi tanggung jawab guru agama dan kewarganegaraan saja tetapi juga menjadi tanggung jawab semua guru. Pada saat ini yang menjadi perhatian penulis diantara pembahasan yang menyangkut tentang pendidikan nilai adalah mendidik nilai kejujuran peserta didik sejak dini melalui sebuah media/sarana yang tepat. Dalam hal ini kantin kejujuran adalah salah satu media/sarana untuk mendidik nilai-nilai kejujuran tersebut.

Kantin kejujuran merupakan wahana pengembangan sikap dan perilaku peserta didik dalam rangka memantapkan dan menginternalisasikan nilai keterbukaan, ketaatan, tanggung jawab, kemandirian, dan keadilan melalui aktivitas ekonomi yang dilakukan secara terbuka dan mandiri dalam rangka membiasakan kehidupan yang jujur, terbuka, dan bertanggungjawab (Dinas Pendidikan Provinsi Jawa Tengah, 2010:6). Tujuan penyelenggaraan kantin kejujuran adalah untuk mendukung kualitas sumber daya manusia melalui upaya menanamkan, menumbuhkan, memelihara, dan mengembangkan nilai-nilai keterbukaan, ketaat asas, tanggung 
jawab, kemandirian, dan keadilan peserta didik melalui praktik pendidikan di lingkungan sekolah secara mandiri dan terbuka (Dinas Pendidikan Provinsi Jawa Tengah, 2010:7).

Kantin kejujuran adalah sebuah kantin dengan desain yang mana peserta didik melayani sendiri mulai dari membeli hingga mengambil uang kembalian (self servis) melayani diri sendiri. Di kantin kejujuran ini hanya tersedia makanan, daftar harga, dan kotak kaleng sebagai tempat uang membayar dan mengambil kembalian. Ketika peserta didik membeli jajan yang ada di kantin kejujuran mereka melayani sendiri membayar sesuai dengan harga yang tertera, ketika uang mereka ada kembalian mereka pun mengambil kembaliannya sendiri. Kantin kejujuran merupakan manifestasi dari pendidikan nilai(akhlak) juga sebagai sarana untuk melatih kejujuran peserta didik.

Berdasarkan pemaparan penjelasan di atas, maka dapat dipahami bahwa kantin kejujuran bisa dijadikan sebagai salah satu sarana untuk menanamkan sifat jujur bagi peseta didik, terutama bagi pendidikan tingkat dasar kantin kejujuran bisa diterapkan sebagai sarana untuk membiasakan kepada peserta didik berbuat jujur, terkait hal di atas penelitian ini akan memaparkan bagaimana konsep pengelolaan kantin kejujuran, bagaimana dampak diterapkannya kantin kejujuran, dan upaya apa saja yang bisa dilakukan untuk mengembangkan kantin kejujuran yang sudah diterapkan di Sekolah tingkat dasar.

\section{METODOLOGI PENELITIAN}

Penelitian ini termasuk penelitian lapangan (field researcd), Sedangkan pendekatan dalam penelitian ini adalah pendekatan deskriptif kualitatif. Pendekatan deskriptif kualitatif lebih mengutamakan penelitian lapangan yang menghasilkan data deskriptif berupa kata-kata tertulis/lisan dari praktisi yang diamati atau menjadi sumber penelitian. Penelitian ini berfokus pada sekolah tingkat dasar yang menerapkan kantin kejujuran sebagai sarana penanaman sifat jujur. Subyek pada penelitian ini kepala sekolah, pengelola kantin kejujuran, guru mata pelajaran Agama, dan peserta didik. Tehnik pengumpulan data pada penelitian ini wawancara, observasi dan dokumentasi. Uji keabsahan data dengan menggunakan teknik triangulasi teknik. 


\section{PEMBAHASAN}

\section{A. Konsep Pengelolaan Kantin Kejujuran}

Konsep pengelolaan kantin kejujuran terbagi menjadi 4 bagian, yakni; perencanaan, pengorganisasian, pelaksanaan, dan pengevaluasian.

\section{Perencanaan}

Perencanaan adalah sejumlah kegiatan yang ditentukan sebelumnya untuk dilaksanakan pada suatu periode tertentu dalam rangka mencapai tujuan yang ditetapkan. Menurut Stoner James, A.F. (dalam Herujito, 2006:89) langkah dasar perencanaan adalah (1) menetapkan tujuan berupa apa yang dibutuhkan atau diinginkan, (2) mendefinisikan situasi saat ini tentang sumber daya yang dimiliki dan data keuangan, (3) menganalisis faktor-faktor eksternal dan internal organisasi, (4) mengembangkan rencana dengan cara memilih alternatif yang sesuai dan menguntungkan. Dalam membuat perencanaan terlebih dahulu harus menganalisis mengenai apa yang harus dikerjakan, mengapa dikerjakan, siapa yang harus mengerjakan, kapan harus dikerjakan, di mana harus dikerjakan, dan bagaimana harus mengerjakan (Herujito, 2006:86). Setiap program yang akan berlangsung, membutuhkan perencanaan yang matang. Tak terkecuali kantin kejujuran.

Perencanaan yang dimaksudkan di atas meliputi, (a) penetapan berdirinya kantin kejujuran, juga termasuk latar belakang berdirinya kantin kejujuran yang diterapkan (b) tujuan di terapkannya kantin kejujuran (c) modal yang digunakan dalam pengadaan/penerapan kantin kejujuran (d) sosialisasi pengadaanpenerapan kantin kejujuran.

\section{Pengorganisasian}

Usman mendefinisikan pengorganisasian merupakan penyusunan struktur organisasi yang sesuai dengan tujuan organisasi, sumber daya yang dimilikinya, dan lingkungan yang melingkupinya (Usman, 2010:146). pengorganisasian merupakan proses penyusunan struktur organisasi yang menempatkan seseorang sesuai dengan keahliannya untuk mencapai tujuan tertentu.

Kantin kejujuran merupakan sebuah program yang tidak luput dari struktur organisasi. Kepengurusan kantin kejujuran di sekolah terdiri dari penanggungjawab 
(kepala sekolah, ketua komite sekolah) pembina kantin atau pengelola kantin (wakil kepala sekolah, kepala tata usaha) dan anggota (guru, ataupun peserta didik).

\section{Pelaksanaan}

Actuating menurut George R. Terry (dalam Herujito, 2006:179) adalah pekerjaan yang dilakukan oleh seorang manajer yang menyebabkan orang-orang lain bertindak. Menurut mekanisme penyelenggaraan kantin kejujuran, barang yang disajikan merupakan barang konsumsi/jajanan peserta didik berupa makanan, minuman, alat tulis sekolah dan perlengkapan sekolah yang mempunyai satuan ukuran yang jelas, baik satuan barang maupun satuan harga. Barang disajikan di atas meja atau di tempat yang mudah dijangkau peserta didik dengan telah diberikan label harga (banderol) yang jelas. Di atas meja disedikan kotak uang untuk tempat uang pembayaran maupun uang pengembalian. Jumlah tiap jenis barang dihitung secara jelas untuk mempermudah pertanggungjawaban keuangan dan barang.

penyelenggaraan kantin kejujuran, pembayaran dan pengembalian dalam penyelenggaraan kantin kejujuran dilakukan melalui mekanisme sebagai berikut:

a. Peserta didik memilih dan mengambil barang sendiri (self service), dan membayar sendiri sesuai dengan harga barang yang dibeli (self payment).

b. Apabila perlu uang kembalian, peserta didik mengambil sendiri sesuai dengan selisih jumlah uang yang dibayarkan dengan jumlah harga barang yang diterima/diambil

Proses pelaksanaan kantin kejujuran tidak lepas dari peran guru PAI yang terus memberi pengarahan kepada peserta didik saat jam pelajaran berlangsung terkait penanaman akhlak khususnya kejujuran.

\section{Pengevaluasian}

Pengevaluasian atau pengawasan adalah tugas untuk mencocokkan sampai di mana program atau rencana yang telah dilaksanakan (Soekarno, 1980:104). Dengan demikian diketahui kelemahan, kekurangan, serta dapat mencari jalan keluar untuk mengatasinya. Sistem evaluasi hanya dilihat dari modal kembali dan masih berjalan. Pengevaluasian dalam hal ini bisa dilakukan setiap hari dinamakan evaluasi harian, evaluasi dilakukan satu bulan sekali dinamakan evaluasi mingguan, evaluasi setiap satu 
bulan sekali namanya evaluasi bulanan, dan evaluasi satu semester sekali namanya evaluasi semesteran.

Menurut pengelola kantin kejujuran dari kedua sekolah modal sudah kembali dan hanya mengelola keuntungan kantin kejujuran merupakan bukti bahwa kantin tidak mengalami kerugian. Dari sinilah dapat disimpulkan bahwa sekolah berhasil menanamkan nilai-nilai kejujuran pada peserta didik. Selain jam mengajar yang padat, sistem kantin yang tidak dijaga memang tidak memungkinkan untuk membuat evaluasi setiap hari karena yang berjalan hati nurani peserta didik, peserta didik yang hari ini tidak membayar bisa saja membayar di kemudian hari.

\section{B. Dampak Kantin Kejujuran terhadap Penanaman Sifat Jujur Peserta Didik}

Tujuan awal berdirinya kantin kejujuran adalah sebagai media penanaman karakter siswa, salah satunya sifat jujur. Menurut tokoh behavioristik, khususnya Skinner berpendapat bahwa lingkungan memiliki pengaruh luar biasa pada proses belajar dan perilaku lebih daripada yang dialami (Sriyanti,dkk, 2013:46). Dari sinilah betapa pentingnya kehadiran lingkungan yang mendukung terbentuknya sikap jujur pada diri peserta didik, salah satunya adalah melalui diterapkannya kantin kejujuran.

Secara harfiah, jujur berarti lurus hati, tidak berbohong, tidak curang. Jujur merupakan nilai penting yang harus dimiliki setiap orang. Jujur tidak hanya diucapkan, tetapi juga harus tercermin dalam perilaku sehari-hari (Naim, 2012:132). Bentuk-bentuk kejujuran menurut Al-Jazairi (2014:302) adalah kejujuran dalam berbicara, bermuamalah, tekad (azzam), berjanji, dan berpenampilan. Fahreza mengemukakan bahwa jujur adalah pondasi dari keseluruhan bangunan kehidupan (Fahreza, 2011:17). Jadi, apabila kejujuran sudah dihayati siswa, maka karakter anak itu akan kokoh. Pada penelitian ini bentuk kejujuran yang muncul dari dampak adanya kantin kejujuran adalah:

a. Jujur dalam berbicara

Salah satu prinsip dasar pengembangan kantin kejujuran adalah keterarahan tujuan. Penyelenggaraan kantin kejujuran ini lebih diarahkan pada tujuan pembentukan, revitalisasi, dan pengaktualisasian nilai-nilai kejujuran, akhlak mulia, budi pekerti, serta penanaman jiwa kewirausahaan. Penyelenggaraan kantin kejujuran tidak dilihat dari segi untung atau ruginya, akan tetapi dilihat dari nilai kejujuran 
yang akan dicerminkan oleh peserta didik. Dilihat dari segi pengakuan yang ada dari para peserta didik yang curang, kantin kejujuran telah melatih peserta didik untuk berbicara jujur karena hakikat kantin kejujuran bukan persoalan uang yang diambil itu kembali atau tidak, akan tetapi pengakuan peserta didik yang memiliki arti bahwa peserta didik tersebut sudahberbicara jujur.

b. Jujur dalam bermuamalah

Muamalah adalah interaksi antar sesama manusia. Contohnya adalah saat berbelanja di kantin kejujuran beberapa narasumber mengaku tidak pernah melakukan kecurangan dalam bertransaksi.

c. Jujur dalam berjanji

Jujur dalam berjanji ini terwujud ketika peserta didik yang curang diberi pembinaan untuk membuat surat yang isinya berjanji pada diri sendiri untuk tidak mengulangi perbuatan tersebut. Indikator keberhasilan salah satunya adalah pembinaan peserta didik tertanamnya sikap jujur, tumbuhnya rasa tanggung jawab, tumbuhnya budaya taat asas, terciptanya rasa keadilan, tumbuhnya sikap terbuka, tumbuhnya akhlak mulia, dan tumbuhnya budaya anti korupsi.

\section{Upaya yang Dilakukan untuk Mengembangkan Kantin Kejujuran}

Pengembangan kantin kejujuran kearah yang lebih baik merupakan keniscayaan yang harus diwujudkan. Pihak sekolah tentu mendukung sepenuhnya dengan pengembangan kantin kejujuran ini. Menanamkan pendidikan akhlak sejak dini, diperlukan sarana dan media yang tepat dalam rangka mentransformasikan pendidikan tersebut kepada anak didik. Salah satu sarana yang dapat digunakan untuk mengajarkan dan membiasakan kejujuran kepada anak didik adalah melalui penerapan kantin kejujuran.

Prinsip Dasar Pengembangan Kantin Kejujuran:

1. Keterarahan tujuan

Penyelenggaraan kantin kejujuran ini lebih diarahkan pada tujuan pembentukan, revitalisasi, dan pengaktualisasian nilai- nilai kejujuran, akhlak mulia, budi pekerti, serta penanaman jiwa kewirausahaan.

2. Keluwesan program

Fleksibilitas penyelenggaraan kantin kejujuran dapat disesuaikan dengan 
budaya sekolah, kemampuan sekolah, waktu, tempat, dan model penyelenggaraan.

3. Pengembangan kemandirian

Penyelenggaraan kantin kejujuran harus mampu menjadi modal dalam pengembangan karakter (character building) peserta didik dengan pembekalan nilainilai kejujuran dan jiwa kewirausahaan dalam menumbuhkembangkan budaya anti korupsi.

4. Daya guna dan hasil guna

Penyelenggaraan kantin kejujuran harus mampu memberdayakan semua elemen sekolah yang dimiliki dan apa yang dilakukan harus mampu memberikan kontribusi penanaman nilai-nilai kejujuran sesuai dengan tujuan yang hendak dicapai.

5. Penumbuhkembangan jiwa kewirausahaan

Penyelenggaraan kantin kejujuran bisa menjadi wahana berlatih wirausaha peserta didik dan upaya menumbuhkembangkan jiwa kewirausahaan (enterpreneur building) peserta didik dengan didasari nilai-nilai kejujuran.

6. Keberlanjutan program

Penyelenggaraan kantin kejujuran harus dilakukan secara sistemik, sistematis dan terus menerus dalam upaya pembentukan karakter peserta didik dalam menumbuhkan budaya anti korupsi.

\section{SIMPULAN}

Kantin kejujuran merupakan sarana yang tepat untuk diterapkan sebagai uapaya penanaman sifat jujur pada peserta didik. Pengelolaan kantin kejujuran meliputi perencanaan, pengorganisasian, pelaksanaan, dan pengevaluasian. Dengan diterapkannya kantin kejujuran di sekolah memberikan dampak yang positif terhapak sifat jujur yang ada pada peserta didik sifat jujur tersebut diantaranya jujur dalam berbicara, jujur dalam bermuamalah dan jujur dalam berjanji. Pengembangan kantin kejujuran kearah yang lebih baik merupakan keniscayaan yang harus diwujudkan. Diantara upaya yang harus dilakukan untuk mengembangkan kantin kejujuran yang ada adalah keterarahan tujuan, keluesan program, pengembangan kemandirian, daya guna dan hasil guna, penumbuhkembangan jiwa kewirausahaan dan keberlanjutan program. 


\section{SARAN}

Untuk sekolah-sekolah yang belum menerapkan kantin kejujuran diharapkan bisa untuk menerapkan kantin kejujuran disekolahnya karena dengan diterapkannya kantin kejujuran disekolah bisa memberikan dampak kepada peserta didik terutama pada penanaman sifat jujur. Terutama untuk sekolah tingkat dasar karena untuk menanamkan nilai/karakter perlu suatu pembiasaan atau suatu hal yang dilakukan dengan berulang-ulang dan bisa melekat menjadi sebuat karakter.

\section{Daftar Pustaka}

Abdud, Nipan. 2000. Menghias Diri dengan Akhlak Terpuji. Yogyakarta: Mitra Pustaka

Al-Jazairi, Jabir. 2014. Minhajul Muslim. Sukoharjo: Pustaka Arafah.

Amar, Abu. 2013. Mizanul Muslim 1. Sukoharjo: Cordovo Mediatama.

Arikunto, Suharsimi. 2010. Prosedur Penelitian Suatu Pendekatan Praktis Edisi Revisi. Jakarta: Rineka Cipta

Darajat, Zakiah. 1995. Pendidikan Islam dalam Keluarga dan Sekolah. Jakarta: Ruhma.

Dinas Pendidikan Provinsi Jawa Tengah. 2010. Pedoman Penyelenggaraan Kantin Kejujuran Provinsi Jawa Tengah. Semarang: Dinas Pendidikan Pemerintah Provinsi Jawa Tengah.

Fahreza, Zaky Ahma. 2011. Menginstal Jujur. Klaten: Etoz Publishing.

Herujito, Yayat M. 2006. Dasar-Dasar Manajemen. Jakarta: PT Grasindo.

Moleong, Lexy J. 2008. Metodologi Penelitian Kualitatif. Bandung: PT Remaja Rosdakarya.

Naim, Ngainun. 2012. Character Building: Optimalisasi Peran Pendidikan dalamPengembangan dan Pembentukan Karakter Bangsa. Jogjakarta: Ar-Ruzz Media.

Sriyanti, Lilik, Muna Erawati, \& Suwardi. 2013. Teori-Teori Belajar. Salatiga: IAIN Salatiga.

Soekarno. 1980. Dasar-Dasar Manajemen. Jakarta: Miswar.

Tim Penyusun Kamus Pusat Bahasa. 2007. Kamus Besar Bahasa Indonesia. Jakarta: Balai Pustaka. 
Usman, Husaini. 2010. Manajemen: Teori, Praktik, dan Riset Pendidikan.Jakarta: Bumi Aksara. 